\title{
Analisis Kemampuan Pemahaman Konsep Matematis Siswa Sekolah Menengah Pertama Berdasarkan Gaya Kognitif
}

\author{
Linda Septiani ${ }^{1}$, Heni Pujiastuti ${ }^{2}$ \\ ${ }^{1 \& 2}$ Pendidikan Matematika, Universitas Sultan Ageng Tirtayasa \\ Email: lindaseptiani98@gmail.com
}

\begin{abstract}
To analyzing the understanding a mathematical conceptionability of junior high school students in terms of the cognitive styles of Field Independent (FI), Field Intermediate (FID), and Field Dependent (FD) is the purpose of this study. The students of MTsN 1 Pandeglang of class IX-C consisting of 20 students became the subjects in this study. By using purposive sampling method, students are grouped based on their cognitive style. Then 2 students from each cognitive style group were taken to measure their understanding a mathematical conception ability. The indicators for the understanding a mathematical conception ability used in this study has seven indicators. The findings show that the student'sunderstanding a mathematical conceptionabilitieshas similarity and different. The students in the Field Independent (FI) cognitivestyle group has similarity of the understanding a mathematical conceptionability that isthey are able to achieve all the indicators contained in the understand a mathematical conception ability.The students in the Field Intermediate (FID) cognitive style groupgrouphave differentthe understand a mathematical conception ability, one student can fulfill all indicators and the other one only fulfills some indicators understand a mathematicalconception ability. It can be inferred even though the students who have the same cognitive style group do not necessarily have the same understand a mathematical conception ability.The students with Field Dependent (FD) cognitive styleonly a few indicators can be achieved by students in indicators of the understand a mathematical conception ability.
\end{abstract}

Keywords: The Understanding a Mathematical ConceptionAbility, Cognitive Style

Abstrak: Menganalisis kemampuan pemahaman konsep matematis yamg dimiliki siswa sekolah menengah pertama jika ditinjau dari gaya kognitif Field Independent (FI), Field Intermediate(FID), dan Field Dependent (FD) merupakan tujuan dari penelitian ini dilakukan. Siswa MTsN 1 Pandeglangkelas IX-C berjumlahkan 20 siswa menjadi subjek dalam penelitian ini. Dengan menggunakan metode purposive sampling, siswa dikelompokkan berdasarkan gaya kognitif yang dimiliki. Kemudian diambil 2 siswadari setiap kelompok gaya kognitif untuk diukur kemampuan pemahaman konsep matematisnya. Indikator untuk kemampuan pemahamanan konsep matematis yang digunakan dalam penelitian ini sebanyak tujuh indikator. Berdasarkan hasil penelitian ini kemampuan pemahaman konsep matematis siswa memiliki persamaan dan perbedaan. Siswa pada kelompok gaya kognitif Field Independent (FI) memiliki persamaan kemampuan pemahaman konsep matematis, yaitu mereka mampu mencapai semua indikator yang terdapat pada kemampuan pemahaman konsep matematis. Siswa pada kelompok gaya kognitif Field Intermediate(FID) memiliki perbedaan kemampuan pemahaman konsep matematis, yaitu salah satu siswa dapat mencapai semua indikator dan siswa lain hanya mencapai beberapa indikator kemampuan pemahaman konsep matematis. Hal ini menunjukkan bahwa walaupun siswa berada dalam kelompok gaya kognitif yang sama belum tentu memiliki kemampuan pemahaman konsep matematis yang sama. Siswa dengan kelompok gaya kognitif Field Dependent (FD) hanya sedikit indikator yang mampu dicapai oleh siswa dalam indikator kemampuan pemahaman konsep matematis.

Kata kunci: Kemampuan Pemahaman Konsep Matematis, Gaya Kognitif

\section{PENDAHULUAN}

Matematika merupakan salah satu mata pelajaran yang diajarkan dan dipelajari oleh siswa pada setiap jenjang pendidikan. Matematika perlu dipelajari oleh semua 
siswa dari sekolah dasar sampai menengah sebagai bekal bagi siswa dengan kemampuan berpikir logis, analitis, sistematis, kritis, kreatif serta kemampuan untuk berkerja sama. Kompetensi tersebut diperlukan agar siswa dapat memiliki kemampuan memperoleh, mengolah dan memanfaatkan informasi untuk bertahan hidup pada keadaan yang selalu berubah-ubah, tidak pasti dan kompetitif (BSNP, 2006).

Karakteristik dalam matematika yaitu matematika merupakan disiplin ilmu yang memiliki objek abstrak, objek/konsep saling berkaitan dan bersifat hirarkis serta konsisten, pembahasannya memerlukan keterampiilan algoritma dan perhitungan serta dapat diterapkan dalam berbagai aspek ilmu maupun penting diterapkan dalam kehidupan sehari-hari. Beberapa karakteristik di ataslah yang menjadi ciri khas tersendiri dalam matematika dibandingkan dengan disiplin ilmu lainnya (Marufi, Pasandaran, \& Yogi, 2018). Oleh sebab itu, siswa dituntut harus memiliki kemampuan pemahaman konsep matematis dan dapat memahami konsep dengan sangat baik. Terutama untuk pemahaman konsep dasar agar dapat memahami konsep-konsep berikutnya. Hal ini dimaksud agar kelak siswa dapat menerapkan ilmu dan konsep matematika yang telah dipelajari tersebut dengan baik dalam kehidupan sehari-hari.

Pemahaman konsep matematis menjadi hal penting dalam matematika. Hal tersebut sesuai dengan tujuan pembelajaran matematika yang pertama pada jenjang pendidikan dasar dan menengah yaitu siswa dapat memahami konsep matematis. Pemahaman konsep matematis merupakan salah satu kecakapan matematis yang harus dikuasi siswa dalam pembelajaran matematika (Karunia \& Mulyono, 2016). Pemahaman konsep matematis adalah suatu tingkat kemampuan yang ketika dimiliki oleh siswa mereka mampu memahami dan menjelaskan maksud atau arti dari suatu konsep yang telah didapat (Marufi et al., 2018; Saleh Yahya, 2017).Berikutindikatorindikator kemampuan pemahaman konsep matematis yang harus dicapai oleh siswa, dikemukakan oleh(Utomo, 2016):(1) menyatakan ulang konsep: siswa mampu mengungkapakan kembali konsep materi yang telah dipelajari baik secara lisan maupun tulisan, (2) mengklasifikasikan objek menurut sifat tertentu sesuai dengan konsepnya: siswa mampu mengklasifikasikanatau mengelompokkan objek berdasarkan sifat-sifat yang terdapat dalam materi yang sesuai menurut jenisnya, (3) memberi contoh dan bukan contoh dari suatu konsep: siswa mampu membedakan contoh dan bukan contoh dari suatu materi yang telah dipelajari baik secara lisan maupun tulisan, (4) menyajikan konsep dalam berbagai bentuk representasi matematis: siswa mampu memaparkan konsep yang bersifat matematis secara berurutan dengan cara menyajikan suatu permasalah dalam bentuk tabel, grafik, diagram, model matematika dan lain sebagainya, (5) mengembangkan syarat perlu atau syarat cukup dari suatu konsep: siswa mampu mengkaji suatu syarat baik syarat perlu maupun syarat cukup terkait suatu konsep materi, (6) menggunakan dan memanfaatkan serta memilih prosedur atau operasi tertentu:siswa mampu menyelesaikan soal atau permasalahan dengan tepat sesuai dengan prosedur, (7) mengaplikasikan konsep atau algoritma pada pemecahan masalah: siswa mampu menggunakan konsep dan prosedur untuk menyelesaikan soal atau permasalahan yang berkaitan dengan kehidupan sehari-hari. 
Secara umum, memahami dalam matematika dan pembelajaran matematika yaitu dengan cara melibatkan tindakan-tindakan untuk mengetahui konsep dan prinsip-prinsip yang berkaitan dengan prosedur atau langkah-langkah dan menciptakan serta menghasilkan hubungan yang bermakna antar konsep satu yang sudah tercipta dengan konsep lain yang baru diterima dan dipelajari. Hal tersebutlah yang diperlukan dalam mempelajari matematika yaitu kemampuan memahami konsep-konsep dalam matematika(Dewi Purwanti, Dinda Pratiwi, \& Rinaldi, 2016). Oleh sebabitu, pembelajaran matematika harus ditekankan ke arah pemahaman konsep.

Seorang siswa dikatakan sudah menguasai suatu konsep dengan sangat baik apabila disertai dengan penerapan atau pengaplikasian. Siswa yang menguasai kemampuan pemahaman konsep matematis ditandai dengan kemampuan siswa untuk menjelaskan suatu materi atau konsep dengan menggunakan kata-kata sendiri tidak terpaku pada buku atau rumus-rumus yang sudah dipelajari, mampu mengabstraksikan sifat yang sama, mampu menjelaskan, membandingkan dan mempertahankan ide-ide yang telah diperoleh dengan ide-ide baru serta mampu membuat generalisasi terhadap suatu konsep (Adiati, 2017; Wulandari \& Muhandar, 2019).

Pembelajaran khususnya pembelajaran matematika, siswa seringkali harus menggunakan dan menempuh cara yang berbeda-beda untuk bisa memahami sebuah konsep yang dipelajari. Siswa memiliki tingkat pemahaman yang berbeda-beda tergantung pada kecepatan belajar dan tingkat kinerja dalam belajar. Ada siswa yang langsung memahami konsep hanya dengan membaca buku saja, namun ada juga siswa yang harus mendengarkan penjelasan guru terlebih dahulu agar memahami konsep. Perbedaan cara dalam belajar inilah yang menunjukkan bahwa ini adalah cara termudah dan lebih disukai bagi siswa untuk mendapatkan sumber belajar dalam proses pembelajaran berlangsung yang bisa kita sebut sebagai gaya belajar (Mulyati, 2015; Tandililing, 2017; Wulandari \& Muhandar, 2019)

Gaya belajar meliputi beberapa komponen, antara lain tipe belajar dan gaya kognitif. Tipe belajar menunjuk pada kecenderungan siswa untuk mempelajari sesuatu dengan cara yang lebih auditif atau visual. Sedangkan gaya kognitif cara khas yang digunakan siswa untuk mengamati dan beraktivitas mental dalam kegiatan kognitif (Yanzhur, Asdor, \& Rusli, 2019).

Cara siswa menerima dan memproses informasi, sikap siswa terhadap informasi maupun kebiasaan yang berhubungan dengan lingkungan belajar dalam pembelajaran merupakan hal-hal yang sangat berkaitan dengan gaya kognitif. Setiap siswa memiliki perbedaan dalam cara memperoleh, menyimpan, dan menerapkan sejumlah pengetahuan. Perbedaan cara tersebut dapat terlihat pada cara siswa memproses pemahamannya berkenaan dengan apa yang dilihat, diingat, dan dipikirkan oleh siswa (Wijaya, 2016; Yanzhur et al., 2019). Dengan demikian, gaya kognitif merupakan karakter individu dari siswa dalam merespons segala informasi yang diterimanya.

Gaya kognitif sendiri terbagi menjadi dua klasifikasi, yaitugaya kognitif Field Independent(FI) dan gaya kognitif Field Dependent (FD) (Witkin, Moore, 
Goodenough, \& Cox, 1977). Bentuk gabungan dalam gaya kognitif untuk Field Independent (FI) dan Field Dependent (FD) yaitu gaya kognitif Field Intermediate (FID).Siswa mampu bekerja mandiri dan mengevaluasi masalah dengan kritis serta memiliki kinerja yang lebih efektif dalam memecahkan masalah matematika merupakan ciri untuk tipe Field Independent (FI) yaitu. Siswa yang cenderung memerlukan petunjuk dan perintah yang lebih jelas dari orang lain dalam menyelesaikan masalah merupakan ciri untuk tipe Field Dependent (FD). Sedangkan siswa yang memiliki kemampuan gabungan antara Field Independetnt (FI) dan Field Dependent (FD) merupakan ciri untuk tipe Field Intermediate (FID) (Guisande, Páramo, Tinajero, \& Almeida, 2007; Nurussafa'at, Sujadi, \& Riyadi, 2016).

Gaya kognitif pada siswa baik Field Independent(FI), Field Intermediate (FID), dan Field Dependent (FD) masing-masing memiliki kemampuan yang berbeda dalam menyelesaikan masalah (Firdausi, Inganah, \& Putri Rosyadi, 2018). Dari ketiga gaya kognitif tersebut, terdapat perbedaan yang dapat mempengaruhi kemampuan pemahaman konsep matematis yang dimiliki oleh masing-masing siswa. Berdasarkan permasalahan perbedaan tersebut, maka tujuan dalam penelitian ini adalah untuk menganalisis kemampuan pemahaman konsep matematis yang dimiliki oleh siswa jika ditinjau dari gaya kognitif Field Independent(FI), Field Intermediate (FID), dan Field Dependent (FD).

\section{METODE}

Penelitian deskriptif dengan pendekatan kualitatif merupakan jenis penelitian yang digunakan dalam penelitian ini. Untuk mengikuti tes Group Embeddeb Figure Test (GEFT), sebanyak 20 siswa kelas IX-CMTsN 1 Pandeglang menjadi subjek yang diambil dalam penelitian ini. Tes Group Embeddeb Figure Test (GEFT) akan dikelompokkan dalam tiap gaya kognitif yaitu Field Dependent (FD), Field Intermediate (FID), dan Field Independent (FI). Metode purposive sampling merupakan langkah selanjutntya yang digunakan untuk mengambil 2 siswa dari masing-masing kelompok sebagai perwakilan dari kelompok gaya kognitif Field Dependent (FD), Field Intermediate (FID), dan Field Independent (FI) untuk mengikuti tes kemampuan pemahaman konsep matematis dan wawancara.

Instrumen yang digunakan dalam penelitian ini yaitu instrumen utama dan instrumen pendukung. Untuk instrumen utama yaitu tes kemampuan pemahaman konsep matematis dan tes Group Embeddeb Figure Test (GEFT) yang dikembangkan oleh Herman. A Witkin dkk pada tahun 1997, sedangkan untuk instrumen pendukung yaitu dengan melakukan wawancara. Pertimbangan untuk melakukan Tes Group Embeddeb Figure Test (GEFT) yaitu karena tes ini disertai latihan terlebih dahulu padabagian awal sehingga siswa dapat mengerjakan tes ini dengan jelas untuk tes berikutnya yaitu untuk bagian kedua dan ketiga, batas waktu yang digunakan untuk mengerjakan tes ini cukup singkat yaitu hanya 15 menit saja, dan untuk mengerjakan 
tes ini tidak perlu memiliki keahlian dan keterampilan khusus(Wulandari \& Muhandar, 2019).

Tes GEFT ini dilakukan kepada siswa guna untuk mengukur kemampuan siswa menemukan sebuah bentuk sederhana yang tersembunyi dalam suatu pola yang kompleks. Tes GEFT ini terdiri dari 3 sesi. Sesi pertama dengan waktu 3 menit dilakukan sebagai latihan dengan soal sebanyak 7 soal. Sesi kedua dan ketigadengan waktu 6 menit untuk setiap sesinya dan masing-masing terdiri dari 9 soal. Penilaian dalam tes GEFT ini dilakukan hanya untuk sesi kedua dan ketiga saja karena pada sesi pertama dilakukan sebagai latihan. Skor dalam pengelompokkan gaya kongnitif siswa berdasarkan tes GEFT dikategorikan pada Tabel 1 berikut ini(Ulya, 2015):

Tabel 1. Pedoman Pegelompokkan Gaya Kognitif

\begin{tabular}{ll}
\hline Skor Test GEFT & Gaya Kognitif \\
\hline $\mathbf{0}-\mathbf{7}$ & Field Dependent (FD) \\
$\mathbf{8}-\mathbf{1 3}$ & Field Intermediate (FDI) \\
$\mathbf{1 4}-\mathbf{1 8}$ & Field Independent (FI) \\
\hline
\end{tabular}

Tes kemampuan pemahaman konsep matematis dalam penelitian ini bertujuan untuk mengukur kemampuan pemahaman konsep matematis subjek berdasarkan indikator yang telah ditentukan. Tes kemampuan pemahaman konsep matematis ini berbentuk tes uraian dengan materi Sistem Persamaan Linear Dua Variabel (SPLDV) dan terdiri dari 7 soal sesuai dengan indikator yang terdapat dalam kemampuan pemahaman konsep matematis. Waktu yang diberikan untuk mengerjakan tes kemampuan pemahaman konsep matematis yaitu selama 50 menit.

Wawancara dalam penelitian ini sebagai instrumen pendukung dan bersifat wawancara semi struktur. Wawancara ini bertujuan untuk memperjelas hasil atau jawaban siswa, mengetahui kebenaran dan keaslian jawaban siswa dan mengetahui bagaimana cara siswa dapat menjawab masalah atau soal dalam tes kemampuan pemahaman konsep matematis.

Penyajian data yang dilakukan dalam penelitian ini yaitu berbentuk uraian dengan kata-kata peneliti dan disertai gambar yang disusun berdasarkan hasil tes GEFT dan tes kemampuan pemahaman konsep matematis (disertai dengan gambar jawaban siswa) serta wawancara siswa. Berdasarkan gaya kognitif yang telah ditentukan, peneliti akan melakukan pengamatan dan menelaah hasil tes yang telah dilakukan siswa. Data yang telah diperoleh tersebut nantinya akan dipaparkan dan dideskripsikan sesuai dengan langkah-langkah siswa dalam menyelesaikan masalah atau soal dalam tes kemampuan pemahaman konsep matematis serta dengan mencantumkan hasil wawancara siwa.

\section{HASIL DAN PEMBAHASAN}

Hasil dalam penelitian ini merupakan hasil yang diperoleh dari tes GEFT, tes kemampuan pemahaman konsep matematis dan juga wawancara yang sudah dilakukan kepada siswa. Berdasarkan tes GEFT yang telah dilakukan kepada 20 siswa kelas IX- 
CMTsN 1 Pandeglang diperolehlah kelompok gaya kognitif Field Independent (FI) sebanyak 6 siswa, kelompok gaya kognitif Field Indetmediate (FDI) sebanyak 9 siswa, dan kelompok gaya kognitif Field Dependent (FD) sebanyak 5 siswa. Metode purposive samplingdigunakan untuk mengambil 2 siswa dari masing-masing kelompok gaya kognitif untuk melakukan tes kemampuan pemahaman konsep matematis.

Siswa yang termasuk dalam kategori Field Independent (FI) berinisial DS dan HRD. Siswa DS memperoleh skor untuk tes GEFT sebesar 15 poin sedangkan siswa HRD sebesar 14 poin. Berdasarkan hasil tes kemampuan pemahaman konsep matematis yang telah dilakukan, DS mampu menjawab semua soal dengan benar. DS dapat memenuhi semua indikator kemampuan pemahaman konsep matematis mulai dari indikator yang pertama sampai yang ke-tujuh. Hal tersebut terlihat pada cara DS dalam menjawab soal-soal yang terdapat dalam tes kemampuan pemahaman konsep matematis. Dibawah ini peneliti menujukkan jawaban DS untuk soal nomor 1 dan 7 berdasarkan hasil tes kemampuan pemahaman konsep matematis.

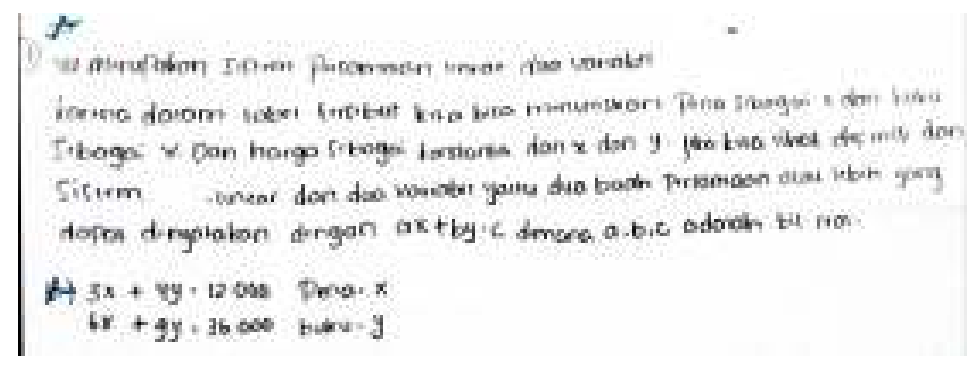

Gambar 1.Jawaban DS Soal Nomor 1

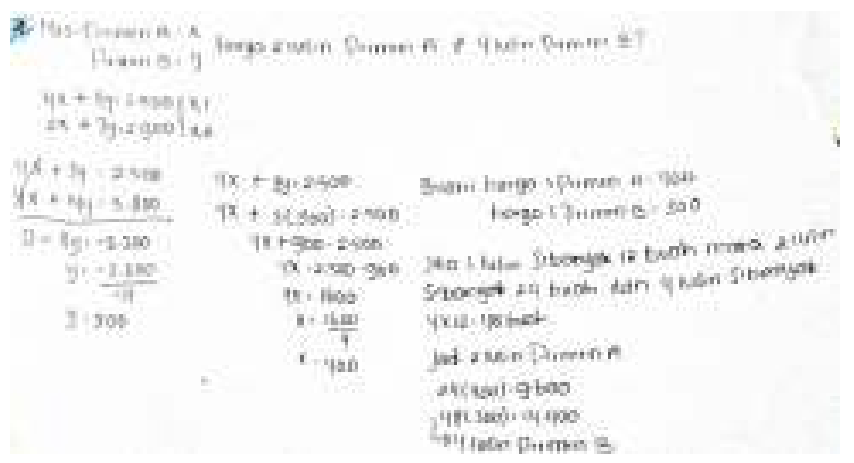

Gambar 2. Jawaban DS Soal Nomor 7

Gambar 1 untuk indikator yang pertama yaitu menyatakan ulang sebuah konsep, DS mampu menyatakan kembali konsep dengan mendefinisikan definisi dari SPLDV dan dapat menuliskan model matematika sesuai dengan definisi SPLDV. Gambar 2 untuk indikator yang ketujuh yaitu mengaplikasikan konsep atau algoritma pada pemecahan masalah, DS mampu menggunakan konsep SPLDV untuk menyelesaikan permasalahan yang berkaitan dengan kehidupan sehari-hari. Cara DS menjawab soal untuk nomor 7 ini sangat baik dan terurut. DS menuliskan jawaban dengan memulai dari memisalkan hal yang diketahui dalam soal dan mengubahnya ke dalam model matematika, menggunakan metode eliminasi dan substitusi dalam melakukan 
perhitungan, serta menuliskan kesimpulan jawaban yang telah didapat. Untuk lebih meyakinkan, peneliti melakukan wawancara dengan DS tentang soal-soal dalam tes kemampuan pemahaman konsep matematis. Tanpa menunjukkan lembar jawaban, peneliti meminta DS untuk menjelaskan kembali cara ia menjawab soal-soal tersebut. DS menjawab pertanyaan dengan sangat baik. DS sangat paham dengan soal-soal dalam tes kemampuan pemahaman konsep matematis baik diungkapkan dalam tulisan ataupun lisan.

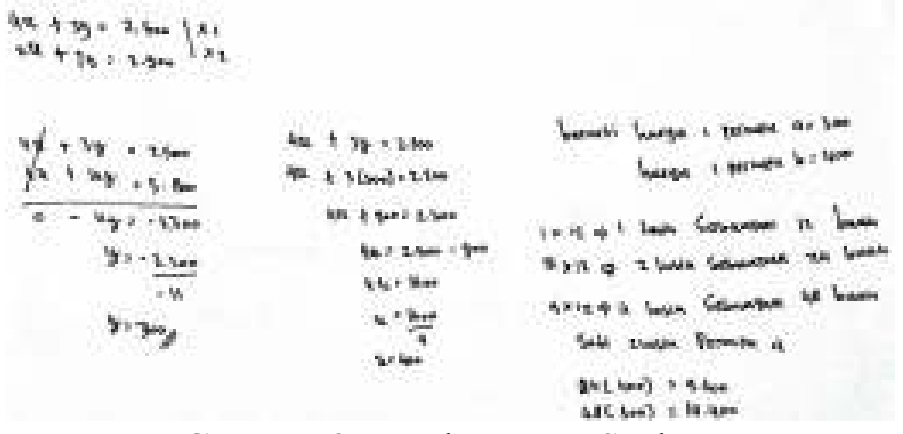

Gambar 3. Jawaban HRD Soal Nomor 7

Siswa HRD seperti DS dapat menjawab semua soal dalam tes kemampuan pemahaman konsep matematis dengan benar. Namun, berdasarkan Gambar 3 terdapat sedikit perbedaan yaitu pada nomor 7. DS menjawab soal nomor 7 dengan terurut. Berbeda dengan HRD yang langsung menjawab dengan perhitungan menggunakan metode eliminasi dan substitusi. Untuk meyakinkan jawaban yang diberikan oleh HRD, peneliti melakukan wawancara. Sama seperti DS, HRD dapat menjawab dan menjelaskan dengan baik jawaban yang telah ia tulis dalam lembar jawaban tes kemampuan pemahaman konsep matematis. Ketika ditanya agarmenjelaskan kembali informasi pada soal nomor 7, HRD dapat menjawab dan menjelaskan dengan benar dan sangat jelas. HRD menjelaskan untuk soal nomor 7 ia menuliskan informasi yang terdapat dalam soal langsung dalam model matematika sehingga ia bisa langsung melakukan perhitungan.

Siswa DS dan HRD dalam penelitian ini menunjukkan bahwa mereka sama-sama dapat menuliskan informasi yang tertera pada soal dan mengaplikasikan rumus atau metode perhitungan yang digunakan untuk menyelesaikan masalah pada soal dengan baik dan benar. Hal tersebut sejalan dengan penelitian yang telah dilakukan oleh (Khairunnisa \& Setyaningsih, 2017; Tyas, 2018) bahwa jika siswa sudah mampu untuk menjelaskan informasi apa saja yang tertera pada soal, informasi tersebut nantinya akan digunakan untuk menyelesaikan masalah yang diberikan oleh soal.Dengan demikian, DS dan HRD telah menunjukkan melalui tes GEFT, tes kemampuan pemahaman konsep matematis dan wawancara bahwa mereka mampu dalam menguasai konsep untuk materi SPLDV, dapat mencapai seluruh indikator kemampuan pemahaman konsepmatematis dan memiliki kemampuan pemahaman konsep matematis dengan sangat baik. 


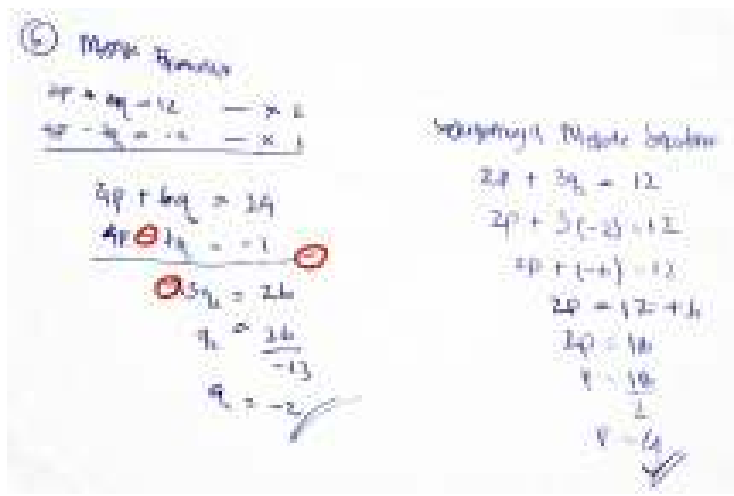

Gambar 4. Jawaban FA Soal Nomor 6

Siswa yang termasuk dalam kategori Field Intermediate (FID) berinisial FA dan MA. Siswa FA memperoleh skor untuk tes GEFT sebesar 11 poin sedangkan siswa MA sebesar 9 poin. Berdasarakan tes kemampuan pemahaman konsep matematis, FA dapat menjawab hampir semua soal dengan benar. FA sudah mampu untuk mencapai semua indikator yang terdapat dalam kemampuan pemahaman konsep matematis. Namun, FA kurang teliti dalam melakukan perhitungan. Hal tersebut dapat terlihat pada Gambar 4. Gambar 4 menunjukkan bahwa FA melakukan metode eliminasi dan substitusi untuk menyelesaikan sistem persamaan yang diketahui pada soal nomor 6 . Untuk soal nomor 6 ini, indikator yang termuat yaitu menggunakan dan memanfaatkan serta memilih prosedur atau operasi tertentu. FA sudah mampu dan paham untuk menggunakan metode penyelesaiannya. Namun, FA kurang teliti dalam tanda operasi pada saat melakukan perhitungan dimetode eliminasi. Tanda yang benar adalah positif $(+)$ namun FA menuliskan (-). Hal tersebut berpengaruh pada metode selanjutnya yaitu metode substitusi serta hasil akhir yang tidak sesuai.

Peneliti melakukan wawancara dengan FA untuk memastikan jawaban yang diberikan oleh FA pada soal-soal dalam tes kemampuan pemahaman konsep matematis. Tanpa menunjukkan lembar jawaban, peneliti meminta FA untuk menjelaskan kembali cara ia menjawab soal-soal tersebut. FA menjawab pertanyaan dengan sangat baik. FA sangat paham dengan soal-soal dalam tes kemampuan pemahaman konsep matematis baik diungkapkan dalam tulisan ataupun lisan. Namun, pada saat peneliti memberitahu bahwa ada sedikit kesalahan pada jawaban ternayata FA baru menyadari bahwa FA kurang teliti pada soal nomor 6 dan melakukan kesalahan untuk tanda operasinya.

Hal yang terjadi pada FA sejalan dengan penelitian yang dilakukan oleh (Jingga, Mardiyana, \& Setiawan, 2017)yang menyatakan kesalahan hitung meliputi siswa melakukan kesalahan dalam memberikan atau menuliskan tanda operasi matematika, siswa melakukan kesalahan dalam melakukan operasi hitung dalam matematika, seperti menjumlah, mengurangkan, mengalikan, dan membagi. 


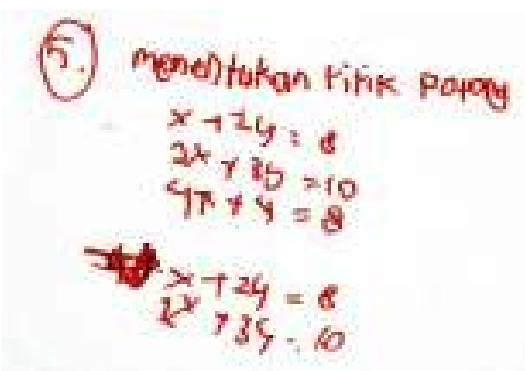

Gambar 5. Jawaban MA Soal Nomor 5

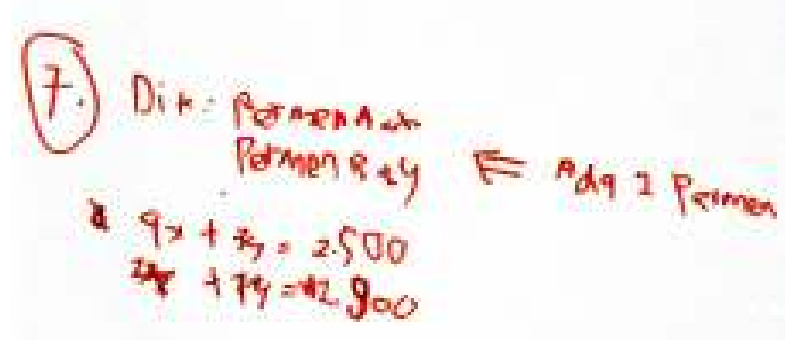

Gambar 6. Jawaban MA Soal Nomor 7

Siswa MA tidak seperti siswa FA yang dapat mencapai semua indikator kemampuan pemahaman konsep matematis. MA belum mampu untuk mencapai semua indikator kemampuan pemahaman konsep matematis. Dari tujuh indikator, MA hanya bisa mencapai lima indikator. Dua indikator yang tidak dicapai oleh MA yaitu mengembangkan syarat perlu atau syarat cukup dari suatu konsep dan mengaplikasikan konsep atau algoritma pada pemecahan masalah. Gambar 5 dan 6 menunjukkan bahwa MA belum mampu untuk menentukan syarat dari mencari titik potong pada SPLDV dan menyelesaikan permasalahan yang berkaitan dengan kehidupan sehari-hari. MA hanya mampu untuk menuliskan kembali informasi yang terdapat pada soal dilembar jawaban.

Peneliti melakukan wawancara dengan MA untuk memastikan jawaban yang diberikan oleh MA pada soal-soal dalam tes kemampuan pemahaman konsep matematis. Tanpa menunjukkan lembar jawaban, peneliti meminta MA untuk menjelaskan kembali cara ia menjawab soal-soal tersebut. MA dapat menjawab dan menjelaskan dengan baik untuk nomor-nomor lain yang MA jawab dengan benar. Namun untuk nomor 5 dan 7, MA menjelaskan bahwa ia memang belum paham untuk mencari titik potong pada SPLDV dan masih merasa kesulitan untuk menyelesaikan permasalahan kehidupan sehari-sehari dengan menggunakan SPLDV.

Perbedaan terdapat antara siswa FA dengan siswa MA yang termasuk dalam kelompok gaya kognitif Field Intermediate (FID). Siswa FA mampu untuk mencapai semua indikator, sedangkan MA hanya mampu mencapai beberapa indikator saja. Berdasarkan perbedaan tersebut, maka siswa yang berada dalam kelomppok gaya kognitif yang sama tidak selalu memiliki kemampuan dalam memecahkan masalah yang sama. Hal tersebut juga didukung dengan penelitian yang telah dilakukan oleh (Fajriah \& Suseno, 2014) yang menyatakan pernyataan yang sama pula. 
Siswa yang termasuk dalam kategori Field Dependent (FD) berinisial AN dan AD. Siswa AN memperoleh skor untuk tes GEFT sebesar 6 poin sedangkan siswa AD sebesar 3 poin. Berdasarkan tes kemampuan pemahaman konsep matematis, AN bisa menjawab soal untuk nomor 1, 2, dan 3 dengan benar. Soal-soal yang dijawab AN sudah mencapai beberapa indikator kemampuan pemahaman konsep matematis yaitu menyatakan ulang sebuah konsep dengan menuliskan kembali definisi SPLDV dan menuliskan suatu model matematika, mengklasifikasi objek menurut suatu sifat tertentu sesuai konsepnya dengan mengelompokkan beberapa persamaan sesuai dengan sifatsifat yang terdapat pada SPLDV, dan memberikan contoh dan bukan contoh dari suatu konsep dengan mengelompokkan beberapa persamaan ke dalam SPLDV atau bukan ke SPLDV.

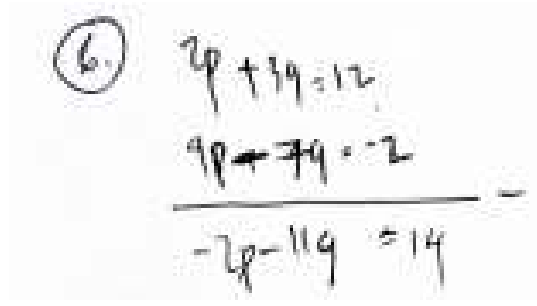

Gambar 7. Jawaban AN Soal Nomor 6

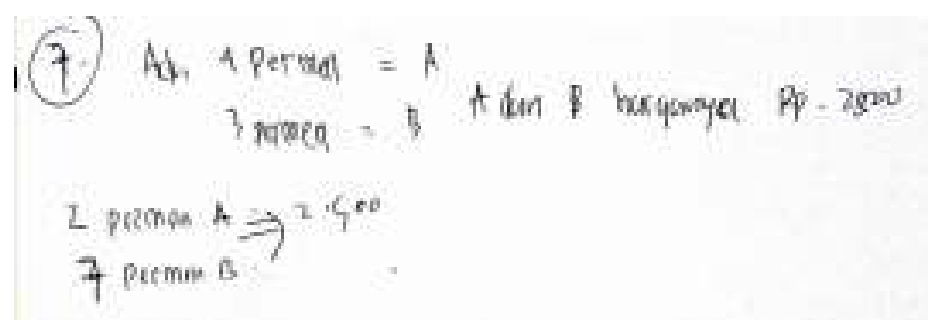

Gambar 8. Jawaban AN Soal Nomor 7

Selain beberapa indikator yang sudah dicapai oleh AN, ada 4 indikator lain yang belum dicapai oleh AN yaitu menyajikan konsep dalam berbagai bentuk representasi matematika, mengembangkan syarat perlu atau syarat cukup dari suatu konsepmenggunakan dan memanfaatkan serta memilih prosedur operasi tertentu, dan mengaplikasikan konsep atau alogaritma pada pemecahan masalah. Berdasarkan Pada Gambar 6, AN belum mampu untuk melakukan operasi penyelesaian dari sistem persamaan yang diketahui.AN hanya menuliskan kembali informasi yang diketahui yang terdapat pada soal.Pada Gambar 7, AN tidak bisa menyelesaikan permasalahan yang berkatian dengan kehidupan sehari-hari karena AN tidak dapat melakukan operasi penyelesaian SPLDV dan hanya menuliskan kembali informasi yang diketahui pada soal.

Peneliti melakukan wawancara dengan AN tentang soal-soal dalam tes kemampuan pemahaman konsep matematis. Tanpa menunjukkan lembar jawaban, peneliti meminta AN untuk menjelaskan kembali cara ia menjawab soal-soal tersebut, baik untuk soal yang dijawab benar atau salah.AN mampu menjelaskan kembali pertanyaan untuk nomor-nomor soal yang ia jawab dengan benar. Namun, alasan AN 
menjawab soal yang hanya AN tuliskan kembali informasinya yaitu karena AN belum paham tentang metode penyelesaian seperti apa yang harus AN gunakan untuk menyelesaikan soal-soal tersebut. Oleh sebab itu juga, AN tidak dapat menyelesaikan soal yang berkaitan dengan permasalahan kehidupan sehari-hari.

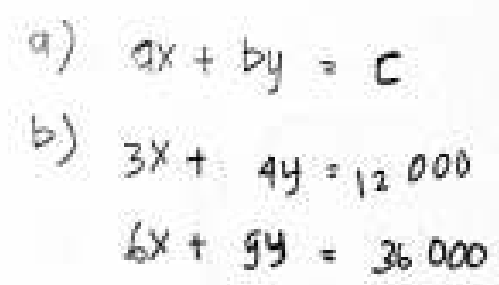

Gambar 9. Jawaban AD Soal Nomor 1

Siswa AD dalam menjawab soal-soal yang terdapat pada tes kemampuan pemahaman konsep matematis hanya mampu menjawab soal nomor 1 saja. Gambar 9, menunjukkan bahwa AD mencapai 2 indikator yaitu menyatakan ulang sebuah konsep dengan menuliskan kembali definisi SPLDV dan menyajikan konsep dalam berbagai bentuk representasi matematika dengan menuliskan model matematika. AD belum mencapai beberapa indikator kemampuan pemahaman konsep matematis lainnya. AD belum mampu menyelesaikan soal yang berkaitan dengan metode penyelesaian SPLDV dan permasalahan kehidupan sehari-hari.

Peneliti melakukan wawancara dengan AD tentang soal-soal dalam tes kemampuan pemahaman konsep matematis. Tanpa menunjukkan lembar jawaban, peneliti meminta AD untuk menjelaskan kembali cara AD menjawab soal-soal tersebut, baik untuk soal yang dijawab benar atau salah. AD dapat menjelaskan kembali dengan baik jawaban yang AD tuliskan untuk nomor 1. Namun, AD tidak dapat menjelaskan untuk soal-soal lainnya karena pada materi SPLDV AD hanya memahami tentang definisi SPLDV dan menuliskan model matematika. Oleh sebab itu, AD belum mampu untuk menyelesaikan soal yang berkaitan dengan metode penyelesaian SPLDV dan permasalahan kehidupan sehari-hari.

Siswa AN dan AD dalam penelitian ini menunjukkan bahwa mereka sama-sama belum mampu untuk menyelesaikan soal-soal yang berkaitan dengan metode penyelesaian SPLDV dan permasalahan kehidupan sehari-hari. Sejalan dengan penelitian yang telah dilakukan oleh(Ariawan \& Nufus, 2017)menyatakan bahwa siswa dengan gaya kognitif Field Dependent (FD) belum mampu untuk mengaitkan dan menyelesaikanpemasalahan dengan kehidupan sehari-hari. Selain itu,siswa dengan kategori Field Independent (FI) mampu menyelesaikan permasalahan yang berkaitan dengan kehidupan sehari-hari sedangkan siswa dengan kategori Field Dependent (FD) belum mampu untuk menyelesaikan permasalahan yang berkaitan dengan kehidupan sehari-harisejalan dengan penelitian yang dilakukan oleh (Sari, 2017). Dengan demikian, AN dan AD telah menunjukkan melalui tes GEFT, tes kemampuan pemahaman konsep matematis dan wawancara bahwa mereka belum mampu dalam 
menguasai konsep untuk materi SPLDV, belum dapat mencapai seluruh indikator kemampuan pemahaman konsep matematis dan memiliki kemampuan pemahaman konsep matematis kurang baik.

\section{SIMPULAN DAN SARAN}

Simpulan yang dapat disampaikan yaitu siswa dengan gaya kognitif Field Independent (FI) memiliki kemampuan pemahaman konsep matematis yang sama. Kedua siswa dengan gaya kognitif Field Independent (FI) sama-sama mampu mencapai semua indikator yang terdapat dalam kemampuan pemahaman konsep matematis. Siswa dengan gaya kognitif Field Intermediate (FID) memiliki kemampuan pemahaman konsep matematis yang berbeda-beda. Ada siswa yang dapat mencapai seluruh indikator kemampuan pemahaman konsep matematis, ada juga yang hanya mencapai beberapa indikator saja. Hal tersebut menunjukkan bahwa walaupun berada dalam kelompok gaya kognitif yang sama belum tentu siswa memiliki kemampuan pemahaman konsep matematis yang sama. Siswa dengan gaya kognitif Field Dependent (FD) indikator yang mampu untuk dicapai hanya sedikit dan belum dapat memahami konsep dari materi yang disudah dipelajari dengan baik.

Saran yang dapat diberikan berdasarkan simpulan diatas, yaitu sebaiknya guru membiasakan siswa mengerjakan soal pemahaman konsep, dan membimbing siswa memahami dan menemukan solusi pemecahan masalah untuk meningkatkan kemampuan pemahaman konsep matematisnya. Dalam menyelesaikan soal pemahaman konsep, guru sebaiknya memperhatikan perbedaan gaya kognitif siswa yang berpengaruh terhadap proses berpikir siswa. Guru hendaknya mengajarkan siswa agar benar-benar memahami konsep dari suatu materi yang diajarkan, bukan hanya memberikan materi dan menghafal rumus saja.

\section{DAFTAR PUSTAKA}

Adiati, A. (2017). Analisis Kemampuan Pemahaman Konsep Matematis Siswa SMP Islam Asy-Syuhada. 1-54.

Ariawan, R., \& Nufus, H. (2017). Profil Kemampuan Koneksi Matematis Mahasiswa dalam Menyelesaikan Masalah pada Mata Kuliah Kalkulus 1 ditinjau berdasarkan Gaya Kognitif. Suska Journal of Mathematics Education, 3(2), 102.

BSNP. (2006). Peraturan Menteri Pendidikan Nasional Republik Indonesia Nomor 22. (November), 1-21.

Dewi Purwanti, R., Dinda Pratiwi, D., \& Rinaldi, A. (2016). Pengaruh Pembelajaran Berbatuan Geogebra Terhadap Pemahaman Konsep Matematis Ditinjau Dari Gaya Kognitif Peserta Didik Kelas VII SMP Negeri 2 Bandar Lampung. Al-Jabar, 7(1), 97-107. 
Fajriah, N., \& Suseno, A. A. (2014). Kemampuan Siswa Sekolah Menengah Pertama dalam Menyelesaikan Masalah Matematika Berdasarkan Gaya Kognitif. Jurnal Pendidikan Matematika, 2(1), 12-21.

Firdausi, M., Inganah, S., \& Putri Rosyadi, A. A. (2018). Kemampuan Koneksi Matematis Siswa Sekolah Menengah Pertama Berdasarkan Gaya Kognitif. MaPan, 6(2), 237-249.

Guisande, M. A., Páramo, M. F., Tinajero, C., \& Almeida, L. S. (2007). Field dependence-independence (FDI) cognitive style: An analysis of attentional functioning. Psicothema, 19(4), 572-577.

Jingga, A. A., Mardiyana, \& Setiawan, R. (2017). Analisis Kesalahan Siswa dalam Menyelesaikan Soal Identitas Trigonometri pada Siswa Kelas X Semester 2 SMA Negeri 1 Kartasutra Tahun Ajaran 2015/2016. Jurnal Pendidikan Matematika Dan Matematika, 1(5), 48-62.

Karunia, E. P., \& Mulyono. (2016). Analisis Kemampuan Pemahaman Konsep Siswa Kelas VII Berdasarkan Gaya Belajar dalam Model Knisley. PRISMA : Prosiding Seminar Nasional Matematika X 2016, 337-346.

Khairunnisa, R., \& Setyaningsih, N. (2017). Analisis Metakognisi Siswa Dalam Pemecahan Masalah Aritmatika Sosial Ditinjau Dari Perbedaan Gender. (Knpmp Ii), 465-474.

Marufi, Pasandaran, R. F., \& Yogi, A. (2018). Pemahaman Konsep Geometri Mahasiswa Berdasarkan Gaya Kognitif Mahasiswa. Proximal Jurnal Penelitian Matematika Dan Pendidikan Matematika, 1(2), 56-67.

Mulyati. (2015). "Identifikasi gaya belajar siswa kelas V SD se-gugus 3 kecamatan Pengasihkabupaten Kulon Progo, tahun 2014 - 2015“. Jurnal Pendidikan Guru Sekolah Dasar, 13(IV).

Nurussafa'at, A. F., Sujadi, I., \& Riyadi. (2016). Soal Cerita Pada Materi Volume Prisma Dengan Fong' S Shcematic Model For Error Analysis Ditinjau Dari Gaya Kognitif Siswa ( Studi Kasus Siswa Kelas VIII Semester II Smp It Ibnu Abbas Klaten Tahun Ajaran 2013 / 2014 ). Jurnal Elektronik Pembelajaran Matematika, 4(2), 174-187.

Purwanti, R. D., Pratiwi, D. D., \& Rinaldi, A. (2016). Pengaruh Pembelajaran Berbantuan GeoGebra Terhadap Pemahaman Konsep Matematis ditinjau dari Gaya Kognitif. Al-Jabar: Jurnal Pendidikan Matematika, 7(1), 115-122.

Saleh Yahya, I.; S. (2017). Pengaruh model pembelajaran problem posing terhadap kemampuan pemahaman konsep matematika siswa kelas vii smp. Jurnal Media Pendidikan Matematika, 4(2), 70-75.

Sari, A. S. (2017). Kemampuan Koneksi Matematika Siswa pada Materi Teorema 
Pythagoras Ditinjau dari Gaya Kognitif. 1-14.

Tandililing, P. (2017). Profil Kemampuan Kognitif Siswa Dalam Menyelesaikan Soal Identitas Trigonometri Berdasarkan Gaya Belajar. J-MPM Jurnal Media Pendidikan MatematikaMedia Pendidikan Matematika, 5(2), 160-164.

Tyas, D. K. F. N. (2018). Profil Pemecahan Masalah Matematika Mahasiswa Menggunakan Langkah Polya Berdasarkan Gaya Kognitif Field Independent Dan Field Dependent. J-MPM Jurnal Media Pendidikan MatematikaMedia Pendidikan Matematika, 6(1), 1-9.

Ulya, H. (2015). Hubungan Gaya Kognitif dengan Kemampuan Pemecahan Masalah Matematika Siswa. Jurnal Konseling Gusjigang, 1(2).

Utomo, J. S. (2016). Analisis Kemampuan Pemahaman Konsep Matematis Siswa SMPN 3 Kalibagor Berdasarkan Emotional Quotient ( Eq).

Wijaya, A. P. (2016). Gaya Kognitif Field Dependent dan Tingkat Pemahaman Konsep Matematis Antara Pembelajaran Langsung dan STAD. Derivat - Jurnal Matematika Dan Pendidikan Matematika, 3(2), 1-16.

Witkin, H. A., Moore, C. A., Goodenough, D., \& Cox, P. W. (1977). Field-Dependent and Field-Independent Cognitive Styles and Their Educational Implications. Review of Educational Research, 47(1), 1-64.

Wulandari, Y. S., \& Muhandar, D. R. (2019). Identifikasi Kemampuan Pemahaman Konsep terhadap Gaya Kognitif Siswa SMP dengan Materi Kubus dan Balok. Prosiding Sesiomadika: Seminar Nasional Matematika Dan Pendidikan Matematika Universitas Singaperbangsa Karawang, 208-227.

Yanzhur, M. Y., Asdor, \& Rusli. (2019). Analisis kesalahan pemahaman konsep dan prinsip pada materi fungsi berdasarkan gaya kognitif siswa. 